\title{
Jurnal
}

Manajemen Kesehatan Indonesia

Volume 7

Nomor 3

Desember 2019

\section{Hubungan Status Gizi Ibu Saat Hamil Dengan Berat Lahir Bayi di Wilayah Kerja Puskesmas Pegantenan Pamekasan}

\author{
Eka Pramudieta*, Endah Mulyani ${ }^{* *}$, Rizka Esty Safriana ${ }^{* *}$, Aidha Rachmawati ${ }^{* *}$ \\ *Jurusan Kebidanan, STIKES Insan Unggul Surabaya \\ ${ }^{* *}$ Fakultas Ilmu Kesehatan, Universitas Muhammadiyah Gresik \\ Email : endahmulyani91@gmail.com
}

\section{ABSTRACT}

Pregnant women with poor nutritional status or experiencing KEK (Chronic Energy Deficiency) tend to give birth to $L B W$ babies and are faced with a greater risk of death compared to babies born to mothers of normal weight. The purpose of this study was to analyze the relationship between maternal nutritional status with a baby's weight born in the Pegantenan Pamekasan Puskesmas Work Area in May June 2018.

This was analytical study with cross sectional approach. The study population amounted to 40 people using simple random sampling obtained a sample of 36 people tested using the chi square test and data retrieval was done using questionnaires.

Result showed that pregnant woman in Pegantenan Pamekasan Health Center Work Area in May - June 2018 almost all had good nutritional status of $80.6 \%$, and the baby's birth weight was almost entirely $>2500 \mathrm{gr}$. The chi-square test results obtained $p=0.003$ and $\alpha=0.05$, then $p<\alpha$, meaning that there was significant relationship. This study concludes that there is a relationship between maternal nutritional status and infant weight for babies born in the working area of Pamekasan Pegantenan Public Health Center in May - June 2018.

Keywords: Pregnant Woman, Nutritional Status, Birth Weight

\section{PENDAHULUAN}

Salah satu indikator bayi dalam kategori sehat jika bayi tersebut terlahir dalam kondisi cukup bulan dengan berat lahir antara 3000 gram sampai 4000 gram, apabila dibawah atau kurang dari 2500 gram dikatakan Berat Badan Lahir Rendah (BBLR). ${ }^{1}$ BBLR termasuk faktor utama dalam peningkatan mortalitas, mordibitas dan disabilitas neonatus, bayi, dan anak serta memberikan dampak jangka panjang terhadap kehidupannya dimasa depan.

Angka kejadian di Indonesia sangat bervariasi antara satu daerah dengan daerah lain, yaitu berkisar antara 9\%$30 \%{ }^{2}$ Hasil Survei Penduduk Antar Sensus (SUPAS) 2015 menunjukkan AKB sebesar 22,23 per 1.000 kelahiran hidup dan BBLR merupakan komplikasi yang menjadi salah satu penyebab kematian terbanyak. ${ }^{3}$ 
Berdasarkan laporan Riset Kesehatan Dasar Indonesia tahun 2013 terdapat 10,4\% anak umur $0-5$ bulan berat lahirnya $<2500$ gr dan terdapat $10,2 \%$ anak dengan berat lahir $<2500$ gr di provinsi Jawa Timur. Data dari profil kesehatan Kabupaten Pamekasan tahun 2014 menunjukkan bahwa Kabupaten Pamekasan merupakan salah satu kabupaten dengan IPM terendah dan merupakan salah satu kabupaten rawan gizi. ${ }^{4}$

Rendahnya IPM di Kabupaten Pamekasan juga ditentukan oleh kecukupan gizi masyarakat. Tablet tambah darah merupakan zat gizi mikro yang sangat diperlukan oleh ibu hamil untuk mencegah melahirkan dengan bayi berat badan lahir rendah (BBLR) dan untuk mencegah perdarahan. Cakupan Ibu hamil mendapatkan tablet tambah darah 90 tablet (Fe 3) selama masa kehamilan di Kabupaten Pamekasan tahun 2014 sebesar $86,86 \%$ dari target $90 \%$. Capaian tersebut sudah mendekati target, namun masih ada sebagian kecil ibu haamil yang belum mendapatkan tablet $\mathrm{Fe}$, disebabkan ketersediaan tablet Fe masih kurang.

Berdasarkan studi pendahuluan didapatkan data bahwa dari bulan januarimaret terdapat $11,25 \%$ bayi lahir dengan berat badan $<2500$ gram dan dari bayi yang lahir < 2500gram 43,75\% ibu mengalami kekurangan energy kronik atau KEK yang ditandai dengan ukuran lingkar lengan atas $<$ 23,5cm. Dari latar belakang tersebut diatas, peneliti tertarik untuk mengadakan penelitian tentang "Hubungan status gizi ibu dengan berat bayi lahir di wilayah kerja Puskesmas Pegantenan Pamekasan“.

\section{METODE PENELITIAN}

Penelitian ini merupakan penelitian analitik dengan desain berupa case control. Populasi dalam penelitian ini adalah seluruh ibu yang bersalin pada bulan Januari Februari 2018 di Puskesmas Pegantenan
Pamekasan yang berjumlah 40 orang. Pengambilan sampel dengan menggunakkan probability sampling dengan teknik simple random samping besar sampel sebesar 36 ibu. Data status gizi ibu dan berat bayi saat lahir diperoleh dari pengisian kuisioner data yang terkumpul akan dianalisis mengunakkan uji statistik chi square dengan $\alpha=0,05$.

\section{HASIL DAN PEMBAHASAN}

Status gizi dan pola makan merupakan faktor yang mempengaruhi penambahan berat badan ibu hamil. Penambahan berat badan ibu hamil akan mempengaruhi berat badan bayi lahir. Status gizi pada masa kehamilan tidak hanya mempengaruhi berat badan bayi lahir, tetapi juga tumbuh kembang anak. Pemenuhan kebutuhan gizi seharusnya tidak hanya dilakukan pada masa kehamilan, tetapi sebaiknya sudah harus menjadi perhatian sejak masa pre-konsepsi (sebelum kehamilan). ${ }^{5,6}$ Penelitian lain bahkan menjelaskan bahwa pemenuhan kebutuhan gizi ibu hamil tidak hanya penting bagi kesehatan ibu dan perkembangan bayi, tetapi juga memiliki peranan penting pada status kesehatan mental ibu. ${ }^{7}$

Tabel 1. Disribusi Frekuensi Karakteristik Ibu Bersalin Berdasarakan Usia, Paritas dan Pekerjaan

\begin{tabular}{lcc}
\hline \multicolumn{1}{c}{ Variabel } & Frekuensi & $\begin{array}{c}\text { Persentase } \\
\text { (\%) }\end{array}$ \\
\hline Usia & & \\
$15-19$ tahun & 4 & 11,1 \\
$20-35$ tahun & 30 & 83,3 \\
35 tahun & 2 & 5,6 \\
Paritas & & \\
Primipara & 7 & 19,44 \\
Multipara & 26 & 72,22 \\
Grandemulti & 3 & 8,34 \\
Pekerjaan & & \\
Swasta & 16 & 44,4 \\
Wiraswasta & 4 & 11,1 \\
PNS & 1 & 2,8 \\
Tidak Bekerja & 15 & 41,7 \\
\hline
\end{tabular}


Berdasarkan tabel 1 dapat dilihat hampir seluruh ibu yang bersalin memiliki rentang usia antara $20-35$ tahun yaitu $83,3 \%$ dan sebagian besar ibu memiliki anak lebih dari satu yaitu sebesar $72,22 \%$ serta hampir setenganya bekerja sebagai pegawai karyawan swasta yaitu sebesar $44,4 \%$.

Tabel 2. Hasil Analisis Chi Square

\begin{tabular}{lcccccc}
\hline \multirow{2}{*}{$\begin{array}{c}\text { Variabel } \\
\text { Independen }\end{array}$} & \multicolumn{5}{c}{ Berat Lahir Bayi } \\
\cline { 2 - 7 } & $\leq 2500 \mathrm{gr}$ & $>2500 \mathrm{gr}$ & \multicolumn{2}{c}{ Jumlah } \\
\cline { 2 - 7 } & $\mathrm{F}$ & $(\%)$ & $\mathrm{F}$ & $(\%)$ & $\mathrm{F}$ & $(\%)$ \\
\hline Baik & 3 & 10,3 & 26 & 89,7 & 29 & 100 \\
Kurang & 5 & 71,4 & 2 & 28,6 & 7 & 100 \\
Jumlah & 8 & 22,2 & 28 & 27,8 & 36 & 100 \\
\hline
\end{tabular}

Berdasarkan tabel 2 dapat dilihat hampir seluruh ibu bersalin yang memiliki status gizi baik melahirkan bayi dengan berat badan lebih $>2500$ gr yaitu 26 bayi $(89,7 \%)$ namun terdapat sebagian kecil ibu yang status gizinya baik melahirkan bayi dengan berat badan $\leq 2500$ gr yaitu 3 bayi (10,3\%). Sebagian besar ibu yang memiliki status gizi kurang melahirkan bayi dengan berat badan $\leq 2500$ gr yaitu 5 bayi $(71,4 \%)$ namun hampir setengah ibu yang memiliki status gizi kurang dapat melahirkan bayi dengan berat badan $>2500$ gr yaitu sebesar $28,6 \%$.

Hasil uji chi square, didapatkan bahwa $\mathrm{p}=0,003$ dan $\alpha=0,05$. Artinya $\mathrm{p}<\alpha$, jadi ada hubungan yang signifikan antara hubungan status gizi dengan berat bayi lahir di wilayah kerja Puskesmas Pegantenan Pamekasan pada bulan Mei - Juni tahun 2018.

Berdasarkan penelitian didapatkan hasil bahwa ada hubungan yang signifikan antara status gizi ibu saat hamil dengan berat bayi saat lahir. Penelitian senada juga dilakukan oleh Gustimaya Putri Mataihu (2015) di Puskesmas Tilango Kabupaten Gorontalo dimana penelitiannya menyimpulkan bahwa terdapat hubungan antara status gizi ibu hamil dengan berat badan bayi baru lahir di Puskesmas Tilango Kabupaten Gorontalo. ${ }^{8}$ Penelitian oleh Verma dan Shrivastava juga menunjukkan bahwa status gizi ibu hamil memiliki pengaruh langsung terhadap berat badan bayi lahir. Ibu hamil yang mengalami malnutrisi memiliki persentase lebih tinggi untuk melahirkan bayi dengan berat badan lahir rendah dibandingkan ibu hamil dengan status gizi yang baik. ${ }^{9}$ Penelitian serupa oleh Akbar, Mansourian dan Kelishadi juga menyatakan bahwa pemenuhan kebutuhan gizi pada ibu hamil menurunkan tingkat kejadian bayi berat badan lahir rendah dan kelahiran prematur. ${ }^{10}$

Masa kehamilan merupakan masa yang sangat menetukan kualitas sumber daya manusia masa depan, karena tumbuh kembang anak sangat ditentukan kondisinya dimasa janin dalam kandungan. Dengan demikian jika keadaan kesehatan dan status gizi ibu hamil baik, maka janin yang dikandungnya akan baik juga dan kesehatan ibu saat melahirkan akan terjamin. ${ }^{11,12}$

Penelitian sebelumnya mengenai status gizi ibu pada awal kehamilan menunjukkan bahwa terdapat hubungan yang signifikan antara pola makan, baik pola makanan pokok dan lauk hewani, terhadap penambahan berat badan ibu hamil. ${ }^{13}$ Penelitian lain juga menunjukkan bahwa terdapat hubungan antara peran asupan zat gizi makronutrien, baik itu energi, protein, lemak, dan karbohidrat pada ibu hamil dengan berat badan lahir bayi. ${ }^{14,15}$

Status gizi ibu hamil dapat diukur secara antropometri atau pengukuran komposisi tubuh dengan mengukur LILA (Lingkar Lengan Atas), disebut KEK bila LILA kurang dari 23,5 cm. LILA merupakan faktor yang dominan terhadap risiko terjadinya Bayi Berat Lahir Rendah (BBLR) dengan Odd Ratio sebesar 8,24. ${ }^{11}$

Variabel luar yang terbukti berhubungan dengan status gizi dan berat bayi lahir dalam penelitian ini dalah usia ibu. 
Usia ibu bersalin dalam penelitian ini paling banyak pada usia reproduksi sehat (20-35 tahun). Usia merupakan salah faktor penting untuk mengurangi angka kesakitan dan kematian ibu. Dalam masa reproduksi sehat dikenal bahwa usia aman untuk kehamilan dan persalinan adalah 20-30 tahun. ${ }^{16}$

Melahirkan anak pada usia ibu yang muda atau terlalu tua mengakibatkan kualitas janin/anak yang rendah dan juga akan merugikan kesehatan ibu. Usia ibu melahirkan yang terlalu muda atau terlalu tua mengakibatkan kualitas janin/anak yang rendah dan juga akan merugikan kesehatan ibu. Karena itu, ibu yang terlalu muda (kurang dari 20 tahun) dapat terjadi kompetisi makanan antara ibunya sendiri yang masih dalam masa pertumbuhan dan adanya perubahan hormonal yang terjadi selama kehamilan.

Status gizi ibu sebelum dan selama hamil dapat mempengaruhi pertumbuhan janin yang sedang dikandung. Bila status gizi ibu normal pada masa sebelum dan selama hamil kemungkinan besar akan melahirkan bayi yang sehat, cukup bulan dengan berat badan normal. Dengan kata lain kualitas bayi yang dilahirkan sangat tergantung pada keadaan gizi ibu sebelum dan selama hamil. Bila mengalami kekurangan gizi selama hamil, akan menimbulkan masalah baik pada ibu maupun janin. Penelitian tahun 2017 di Palangkaraya menunjukkan bahwa terdapat hubungan signifikan antara kenaikan berat badan ibu hamil dengan berat lahir bayi. Semakin bertambah kenaikan berat badan ibu hamil, maka semakin bertambah pula berat lahir bayi. ${ }^{17}$

Penelitian lain mengenai kadar vitamin D pada ibu hamil dan berat bayi lahir menunjukkan bahwa ibu hamil penting untuk memenuhi kebutuhan gizi khususnya vitamin D. Vitamin D yang cukup penting bagi ibu hamil karena dapat membantu kinerja kalsium pada trimester III dan dapat membantu kenaikan berat bayi lahir. ${ }^{18}$

\section{KESIMPULAN}

Variabel status gizi ibu pada saat hamil berhubungan signifikan dengan berat bayi saat lahir. Agar masyarakat keseluruhan baik dari petugas kesehatan maupun masyarakat awam turut serta berperan aktif dalam peningkatan status gizi dari masa remaja karena persiapan kehamilan bisa dimulai dari masa remaja agar nantinya menjadi ibu dengan kondisi kesehatan reproduksi yang optimal.

\section{DAFTAR PUSTAKA}

1. Endriana SD, Indrawati ND, Rahmawati A. Hubungan Umur dan Paritas Ibu dengan Berat Bayi Lahir di RB Citra Insani Semarang Tahun 2012. J Kebidanan 2013; 2: 77-83.

2. Kemenkes RI. Profil Kesehatan Indonesia Tahun 2016. Jakarta, 2017.

3. Kementerian Kesehatan RI. Profil Kesehatan Indonesia 2015. Jakarta: Kementerian Kesehatan Republik Indonesia, 2015.

4. Dinas Kesehatan Provinsi Jawa Timur. Profil Kesehatan Provinsi Jawa Timur 2015. Surabaya: Dinas Kesehatan Provinsi Jawa Timur, 2015.

5. Christian P, Mullany LC, Hurley KM, et al. Nutrition and maternal, neonatal, and child health. Semin Perinatol 2015; 39: 361-372.

6. King JC. A Summary of Pathways or Mechanisms Linking Preconception Maternal Nutrition with Birth Outcomes. J Nutr 2016; 146: 1437S-1444S.

7. Leung BMY, Giesbrecht GF, Letourneau N, et al. Perinatal nutrition in maternal mental health and child development: Birth of a pregnancy cohort. Early Hum Dev 2016; 93: 1-7.

8. Mataihu GP. Hubungan Status Gizi Ibu Hamil dengan Berat Badan Bayi Baru 
Lahir di Puskesmas Tilango Kabupaten Gorontalo. Universitas Negeri Gorontalo, 2015.

9. Verma S, Shrivastava R. Effect of Maternal Nutritional Status on Birth Weight of Baby. Int $J$ Contemp Med Res 2016; 3: 943-945.

10. Akbari Z, Mansourian M, Kelishadi R. Relationship of the intake of different food groups by pregnant mothers with the birth weight and gestational age: Need for public and individual educational programs. J Educ Health Promot; 4. Epub ahead of print 2015. DOI: $10.4103 / 2277-9531.154109$.

11. Proverawati A, Ismawati C. Berat Badan Lahir Rendah. Yogyakarta: Nuha Medika, 2010.

12. Coelho N de LP, Cunha DB, Esteves APP, et al. Dietary Patterns in Pregnancy and Birth Weight. Rev Saude Publica; 49.

13. Budhi Harti L, Kusumastuty I, Hariadi I. Hubungan Status Gizi dan Pola Makan terhadap Penambahan Berat Badan Ibu Hamil (Correlation between Nutritional Status and Dietary Pattern on Pregnant Mother's Weight Gain). Indones J Hum Nutr 2016; 3: 54-62.

14. Saimin J, Amalia AR, Ashaeryanto, et al. Konsumsi Makanan Ibu Hamil Berhubungan dengan Berat Badan Lahir Bayi di Daerah Pesisir. MEDULA 2019; 6: 570-576.

15. Syari M, Serudji J, Mariati U. Peran Asupan Zat Gizi Makronutrien Ibu Hamil terhadap Berat Badan Lahir Bayi di Kota Padang. J Kesehat Andalas 2015; 4: 729-736.

16. Manuaba IAC. Ilmu Kebidanan, Penyakit Kandungan, dan KB Untuk Pendidikan Bidan. Edisi 2. Jakarta: Buku Kedokteran EGC, 2010.

17. Mawaddah S, Muhtar CM. Kenaikan Berat Badan Ibu Hamil Terhadap Berat Lahir Bayi di Kota Palangkaraya.
Mahakam Midwifery J 2018; 2: 230240.

18. Putri NI, Lipoeto NI, Rita RS, et al. Hubungan Kadar Vitamin D pada Ibu Hamil dengan Berat Bayi Lahir di Kabupaten Tanah Datar dan Kabupaten Solok. J Ilm Univ Batanghari Jambi 2019; 19: 61-64. 